\title{
EMPLOYEE ATTITUDES TOWARD CHANGE IN PUBLIC SECTOR ORGANIZATION
}

\author{
Mega Asri Zona* \\ Jurusan Manajemen, Fakultas Ekonomi, Universitas Negeri Padang, Indonesia
}

\begin{abstract}
Abstrak
Penelitian ini bertujuan untuk menguji empat konstruk yang mewakili sikap karyawan terhadap perubahan organisasional, yaitu; kesiapan untuk berubah, komitmen terhadap perubahan organisasi, keterbukaan terhadap perubahan dan sinisisme terhadap perubahan organisasi. Penelitian ini adalah jenis penelitian deskriptif yang bertujuan untuk memberikan deskripsi dan menggambarkan situasi yang sedang terjadi. Populasi dalam penelitian ini adalah karyawan organisasi sektor publik yang sedang mengalami perubahan di Provinsi Sumatera Barat. Teknik pengambilan sampel yang digunakan pada penelitian ini adalah purposive sampling. Metode survei digunakan dengan membagikan kuesioner kepada karyawan organisasi sektor publik di Sumatera Barat. Jumlah responden dalam penelitian ini adalah 100 responden. Hasil penelitian menunjukkan bahwa keterbukaan terhadap perubahan memiliki rata-rata tertinggi, diikuti oleh kesiapan untuk berubah, komitmen terhadap perubahan dan sinisisme terhadap perubahan organisasi. Ini berarti bahwa karyawan di organisasi publik di Sumatera Barat bersedia untuk mengakomodasi dan menerima perubahan.
\end{abstract}

Kata Kunci: Sinisisme terhadap perubahan organisasi; Komitmen terhadap perubahan; Keterbukaan terhadap perubahan; Kesiapan untuk berubah

\begin{abstract}
This research aim to examine four constructs that represent employee attitudes towards organizational change; readiness for change, commitment to change, openness to change and cynicism about organizational change. This research would help the public organization to overcome changes.. This research is a type of descriptive research that aims to describe the nature of something that is ongoing at the time the research is conducted and examine the cause of a particular symptom. The population in this study are employees of public sector organizations that are undergoing organizational changes in the Province of West Sumatra. The sampling technique in this study uses purposive sampling where the sampling technique is based on a certain criterion. In this case the criteria for sampling are employees with organizations that are undergoing changes. The data collection technique used was a survey by distributing questionnaires to employees of public sector organizations in West Sumatra. The number of respondents in this study were 100 respondents. The result shows that openness to change have the highest mean, followed by readiness to change, commitment to change and cynicism about organizational change. It means that employees in public organization in West Sumatra are willing to accommodate and accept change.
\end{abstract}

Keywords: employee attitudes towards organizational change; readiness for change; commitment to change; openness to change; cynicism about organizational change

Article History: Received: (17-01-2020); Revised: (08-03-2020); and Published: (30-04-2020) Copyright (C) 2020 Mega Asri Zona

How to cite this article: Zona, M. A. (2020). Employee Attitudes Toward Change In Public Sector Organization. Management Insight: Jurnal IImiah Manajemen. 15(1), 19-32.

*Correspondence to: Mega Asri Zona

E-Mail: megaasrizona@fe.unp.ac.id 


\section{PENDAHULUAN}

Penelitian Choi (2011) menunjukkan bahwa terdapat empat konstruk yang mewakili sikap karyawan terhadap perubahan organisasional; kesiapan untuk berubah, komitmen terhadap perubahan organisasi, keterbukaan terhadap perubahan dan sinisisme terhadap perubahan organisasi. Keempat konstruk tersebut dianggap sebagai penentu keberhasilan atau kegagalan sebuah perubahan yang berlangsung di organisasi. Hal ini dikarenakan dalam proses perubahan, organisasi harus dapat memainkan peran dalam mengelola sikap karyawan untuk kemudian mengkoordinasikan mekanisme perubahan, menyesuaikan kegiatan operasional dengan strategi, membangun struktur dan mengembangkan penghargaan (Bommer, Rich, \& Rubin, 2005).

Penelitian ini penting karena banyak peneliti sebelumnya berpendapat bahwa upaya perubahan sering gagal karena para pemimpin yang bertanggung jawab atas perubahan sering meremehkan pentingnya sikap individu (karyawan) dalam proses perubahan (Armenakis, Harris, \& Mossholder, 1993). Penelitian tersebut juga menyarankan agar penelitian selanjutnya lebih fokus pada perspektif perubahan tingkat mikro dan fokus pada individu dalam organisasi (Bommer et al., 2005). Penelitian tentang perubahan telah menemukan bahwa keberhasilan perubahan tergantung pada partisipasi individu, dalam hal ini karyawan perusahaan. Hal yang sama juga berlaku di organisasi sektor publik.

Sejauh ini, organisasi sektor publik di Indonesia sering dianggap sebagai organisasi yang tidak efisien. Selain itu, organisasi sektor publik juga memiliki karakteristik yang sangat birokratis dengan penekanan pada aturan, prosedur, hierarki, dan proses pengambilan keputusan formal.

Saat ini, semua organisasi sektor publik di Indonesia sedang melakukan perubahan organisasi. Perubahan ini disebut reformasi birokrasi. Tujuan dari perubahan ini adalah agar organisasi sektor publik menjadi sebuah organisasi yang lebih efisien, efektif dan juga akuntabel (http://www.menpan.go.id/reformasibureaucracy). Reformasi birokrasi pada dasarnya adalah upaya untuk melakukan reformasi mendasar dan mengubah sistem suatu organisasi, terutama dalam aspek kelembagaan organisasi, prosedur yang terdapat di organisasi dan sumber daya manusia.

Berbagai masalah yang terjadi dalam implementasi yang menyebabkan sistem tidak berfungsi atau tidak diharapkan berjalan dengan baik harus ditata ulang atau dimutakhirkan melalui reformasi birokrasi. Reformasi birokrasi dilaksanakan untuk mewujudkan organisasi sektor publik yang lebih baik.

Reformasi birokrasi itu sendiri adalah perubahan strategis untuk mereformasi karyawan dalam organisasi publik agar menjadi lebih efisien dan efektif dalam melaksanakan tugas dan tanggung jawabnya sebagai pegawai pemerintah dan bagian dari pembangunan nasional. Selain itu, dengan kemajuan pesat ilmu pengetahuan, 
teknologi informasi dan komunikasi serta lingkungan strategis, perubahan menuntut birokrasi pemerintah untuk direformasi dan disesuaikan dengan tuntutan masyarakat. Oleh karena itu, organisasi sektor publik harus mengambil perubahan mendasar, komprehensif, dan sistematis, sehingga tujuan dan sasaran yang ditetapkan dapat tercapai secara efektif dan efisien.

Penelitian ini ingin mengukur sikap karyawan pada organisasi sektor publik di Sumatera Barat terhadap perubahan yang terjadi. Sikap ini terdiri dari kesiapan untuk berubah, komitmen terhadap perubahan, keterbukaan terhadap perubahan dan sinisisme terhadap perubahan organisasi.

\section{TINJAUAN PUSTAKA}

\section{Readiness for Change (Kesiapan untuk Berubah)}

Ketika perubahan terjadi, karyawan mencoba memahami lingkungan baru dan menarik kesimpulan tentang kemungkinan hasil dari perubahan ini dengan secara aktif mencari informasi. Ini akan membuat mereka memiliki asumsi, kesan dan harapan tentang perubahan yang terjadi. Asumsi, kesan dan harapan ini akan mendorong kesiapan karyawan untuk perubahan organisasi (Choi \& Ruona, 2011).

Kesiapan karyawan untuk berubah adalah keyakinan, perasaan, dan niat karyawan sebagai anggota organisasi terkait sejauh mana perubahan diperlukan dan kapasitas organisasi untuk membuat perubahan itu berhasil (Armenakis et al., 1993). Kesiapan untuk perubahan menunjukkan sejauh mana karyawan memiliki pandangan positif tentang perlunya organisasi untuk melakukan perubahan, dan juga sejauh mana karyawan percaya bahwa perubahan akan memiliki dampak positif pada diri mereka sendiri dan organisasi. Perusahaan yang mengadopsi perspektif pengembangan organisasi memandang perubahan sebagai upaya yang disengaja untuk membuat perbedaan dalam pengaturan kerja organisasi dengan tujuan meningkatkan pengembangan individu dan meningkatkan kinerja organisasi.

\section{Commitment to Change (Komitmen terhadap Perubahan)}

Komitmen adalah salah satu aspek penting dalam menjelaskan perilaku karyawan dalam suatu organisasi (Ahmad \& Cheng, 2018). Komitmen untuk berubah adalah kemauan untuk memberikan upaya terbaik untuk perubahan yang terjadi di organisasi, sebuah konstruk yang menggambarkan sikap positif dan proaktif terhadap perubahan (Fedor, Caldwell, \& Herold, 2006). Komitmen untuk berubah tidak hanya menunjukkan sikap positif terhadap perubahan, tetapi juga sikap yang sejalan dengan perubahan, niat untuk mendukung, dan keinginan untuk bekerja demi keberhasilan perubahan organisasi.

Komitmen terhadap perubahan mencerminkan niat perilaku proaktif untuk mendukung dan bekerja menuju keberhasilan yang menjadi tujuan perubahan organisasi (Fedor et al., 2006). Ketika perubahan telah diinternalisasi, individu terlibat 
dalam kegiatan yang berorientasi tujuan untuk memenuhi kebutuhan diri mereka sendiri dan orang-orang yang ada di organisasi. Antusiasme, investasi energi tinggi, dan kegigihan mencirikan komitmen di tingkat internal. Untuk memahami komitmen karyawan terhadap perubahan dapat dilakukan melalui pengukuran terhadap konten perubahan, konteks perubahan, proses perubahan, dan kepemimpinan dalam suatu organisasi. Perubahan konten adalah salah satu masalah utama dalam literatur reformasi sektor publik tetapi juga menerima banyak perhatian dalam literatur manajemen perubahan. Ini terkait dengan inisiatif perubahan dan bagaimana perubahan yang terjadi dalam organisasi dirasakan oleh karyawan. Perubahan konten juga dikenal sebagai valensi dan kompatibilitas pribadi. Personal valensi juga disebut sebagai dampak perubahan yang dirasakan, terkait dengan implikasi yang dirasakan karyawan tentang perubahan organisasi pada mereka secara pribadi, dengan mengacu pada dampak yang diharapkan pada faktor intrinsik dan ekstrinsik (Choi, 2011). Sedangkan kesesuaian terkait dengan persepsi mereka tentang manfaat potensial dari perubahan organisasi (Fedor et al., 2006). Selanjutnya, konteks perubahan, mengacu pada karakteristik organisasi dan keanggotaannya yang mendahului perubahan organisasi (Herscovitch \& Meyer, 2002). Faktor-faktor yang terkait dengan konteks perubahan fokus pada kondisi atau keadaan yang ada di lingkungan internal dan eksternal organisasi yang telah terbukti mempengaruhi perubahan organisasi (Bommer et al., 2005). Selanjutnya yaitu proses perubahan, mengacu pada intervensi dan proses yang terjadi dalam mengimplementasikan inisiatif perubahan. Ini berkaitan dengan tindakan dan strategi yang diambil oleh agen perubahan selama implementasi perubahan yang diusulkan (Fedor et al., 2006). Sudah lama diyakini bahwa proses perubahan organisasi terkait dengan komitmen karyawan terhadap perubahan itu sendiri.

\section{Openness to Change (Keterbukaan terhadap Perubahan)}

Keterbukaan terhadap pengalaman adalah salah satu dari Big Five Personality yang didefinisikan sebagai individu yang memiliki minat terhadap hal-hal baru. Perilaku individu ini dikaitkan dengan sikap terbuka terhadap perubahan. Individu yang sangat terbuka umumnya kreatif, penasaran, dan sensitif (Choi, 2011). Keterbukaan terhadap perubahan adalah keinginan untuk mendukung perubahan dan perasaan positif tentang konsekuensi potensial (manfaat) dari perubahan tersebut (Devos, Buelens, \& Bouckenooghe, 2007). Individu yang terbuka terhadap perubahan juga bersedia mengakomodasi dan menerima perubahan. Ketika perubahan terjadi, anggota organisasi yang terbuka untuk perubahan akan mendukung implementasi perubahan. Semua upaya akan dilakukan untuk membuat perubahan ini berhasil. Berfokus pada keterbukaan terhadap perubahan, Devos et al. (2007) meneliti bagaimana lingkungan dan sirkulasi informasi mempengaruhi sikap karyawan terhadap perubahan organisasi. Mereka menemukan bahwa ketika karyawan memiliki informasi yang cukup tentang 
peran dan keadaan mereka dalam organisasi pada tahap awal perubahan dan ketika mereka merasa termasuk dalam penugasan dan jaringan informasi sosial, mereka cenderung bersikap lebih terbuka terhadap perubahan. Choi (2011) juga menunjukkan bahwa persepsi kualitas informasi yang diterima tentang suatu perubahan dapat mempengaruhi keterbukaan karyawan untuk berubah.

\section{Cynicism about Organizational Change (Sinisme terhadap Perubahan Organisasi)}

Sinisisme terhadap perubahan organisasi merupakan hal yang penting karena sikap ini adalah salah satu konstruk yang menentukan apakah perubahan akan diterima atau ditolak. Sikap ini nantinya akan mengarah pada keberhasilan atau kegagalan suatu perubahan di organisasi. Sinisisme adalah sikap paling negatif yang dapat dimiliki oleh karyawan terhadap suatu organisasi (Arbaugh, 2002). Namun, karyawan tidak hanya dapat dibagi menjadi karyawan yang sinis dan tidak sinis, karena setiap karyawan memiliki tingkat sinisisme yang berbeda-beda. Sinisisme pada tingkat yang lebih rendah berbeda dari sinisme pada tingkat yang lebih tinggi, yang akan berdampak pada proses dan hasil dari program perubahan (Choi, 2011). Sinisisme terhadap perubahan organisasi menghasilkan perubahan nyata seperti emosi, kelelahan, komitmen organisasi yang lebih rendah, dan niat yang lebih rendah untuk terlibat dalam organisasi (Arbaugh, 2002). Dari perspektif teori transisi sosial, sinisisme tentang perubahan organisasi merupakan hasil dari perumusan harapan, pengalaman kekecewaan karena gagal memenuhi harapan ini, dan kekecewaan berikutnya (Reichers, Wanous, \& Austin, 2010).

\section{METODE PENELITIAN}

Penelitian ini merupakan jenis penelitian deskriptif yang bertujuan menggambarkan dan mendeskripsikan kejadian yang tengah berlangsung pada saat riset dilakukan dan memeriksa penyebab dari suatu kejadian tertentu. Penelitian ini ingin memberikan gambaran dan deskripsi mengenai sikap karyawan terhadap perubahan organisasional, yang terdiri dari kesiapan untuk berubah, komitmen terhadap perubahan organisasi, keterbukaan terhadap perubahan dan sinisisme terhadap perubahan organisasi.

Populasi dalam penelitian ini adalah pegawai organisasi sektor publik yang sedang mengalami perubahan organisasional yang terdapat di Provinsi Sumatera Barat. Populasi dalam penelitian ini tidak diketahui, oleh karena itu teknik pengambilan sampel akan menggunakan salah satu teknik non-probability sampling yaitu purposive sampling, dimana teknik pengambilan sampel berdasarkan suatu kriteria tertentu. Dalam penelitian ini yang dijadikan kriteria untuk pengambilan sampel adalah pegawai dengan organisasi yang sedang mengalami perubahan. Teknik pengumpulan data yang digunakan adalah survei dengan penyebaran kuisioner kepada pegawai organisasi 
sektor publik yang ada di Sumatera Barat. Jumlah responden dalam penelitian ini adalah 100 orang responden.

\section{Karakteristik Responden}

Deskripsi responden didapatkan melalui kuesioner yang telah diisi oleh responden terlebih dahulu, dan didapatkan hasil berupa karakteristik responden berdasarkan jenis kelamin, umur, pendidikan dan masa kerja.

a. Berdasarkan Jenis Kelamin

Karakteristik responden berdasarkan jenis kelamin dapat dilihat pada tabel berikut:

\begin{tabular}{|c|c|c|c|}
\hline No & Jenis Kelamin & Frekuensi & Persentase (\%) \\
\hline 1 & Laki-Laki & 35 & 35 \\
\hline \multirow[t]{2}{*}{2} & Perempuan & 65 & 65 \\
\hline & Jumlah & 100 & $100 \%$ \\
\hline
\end{tabular}

Sumber: Data Primer (2019)

Berdasarkan tabel diatas mengenai karakteristik responden berdasarkan jenis kelamin dapat disimpulkan bahwa responden penelitian ini yang paling banyak adalah pegawai perempuan yaitu berjumlah 65 orang dengan persentase sebesar $65 \%$. Sedangkan pegawai laki-laki hanya sebanyak 35 orang dengan persentase sebesar $35 \%$. Jadi dapat disimpulkan bahwa distribusi karakteristik responden berdasarkan jenis kelamin pada pegawai sektor publik Sumatera Barat yang diteliti didominasi oleh pegawai perempuan.

b. Berdasarkan Umur

Karakteristik responden berdasarkan umur dapat dilihat pada tabel berikut:

Tabel 2. Karakteristik Responden Berdasarkan Umur

\begin{tabular}{cccc}
\hline No & Jenis Kelamin & Frekuensi & Persentase (\%) \\
\hline 1 & & & \\
2 & $26-30$ & 17 & 17 \\
3 & $31-35$ & 22 & 22 \\
4 & $36-40$ & 22 & 22 \\
5 & $41-45$ & 19 & 19 \\
6 & $46-50$ & 10 & 10 \\
7 & $>51$ & 5 & 5 \\
& Jumlah & 100 & 5 \\
\hline
\end{tabular}

Sumber: Data Primer (2019)

Hasil penelitian menunjukan bahwa pengelompokan responden berdasarkan umur seperti tabel diatas dimana proporsi terbesar berada pada usia antar 26-30 tahun dan 31-35 tahun sebanyak 22 orang dengan persentase sebesar $22 \%$. Hal ini berarti pegawai yang bekerja pada sektor publik di Sumatera Barat didominasi oleh 
pegawai yang berusia produktif. Sedangkan usia 46-50 tahun dan juga $>51$ tahun memperoleh persentase terendah yaitu sebesar $5 \%$.

c. Berdasarkan Pendidikan

Karakteristik responden berdasarkan pendidikan pada penelitian ini dapat dilihat pada tabel berikut:

\begin{tabular}{cccc}
\multicolumn{4}{c}{ Tabel 3. Karakteristik Responden Berdasarkan Pendidikan } \\
\hline No & Jenis Kelamin & Frekuensi & Persentase (\%) \\
\hline 1 & SD & - & - \\
2 & SMP & - & - \\
3 & SMA & 3 & 3 \\
4 & D3 & 9 & 9 \\
5 & S1 & 79 & 79 \\
6 & S2 & 8 & 8 \\
7 & S3 & 1 & 1 \\
\hline
\end{tabular}

Sumber: Data Primer (2019)

Berdasarkan Tabel 3, mengenai karakteristik responden berdasarkan pendidikan dapat disimpulkan bahwa responden yang banyak ditemui dalam penelitian ini adalah responden yang berpendidikan S1 yaitu sebanyak 79 orang dengan persentase $79 \%$. Untuk responden yang berpendidikan SD dan SMP tidak ditemukan pada pegawai sektor publik Sumatera Barat yang diteliti. Hal ini dapat disimpulkan bahwa pegawai sektor publik Sumatera Barat yang menjado objek penelitian didominasi oleh pegawai dengan pendidikan S1.

d. Berdasarkan Masa Kerja

Karakteristik berdasarkan masa kerja dapat dilihat pada tabel berikut:

\begin{tabular}{cccc}
\multicolumn{4}{c}{ Tabel 4. Karakteristik Responden Berdasarkan Masa Kerja } \\
\hline No & Jenis Kelamin & Frekuensi & Persentase (\%) \\
\hline 1 & $<5$ & 33 & 33 \\
2 & $6-10$ & 31 & 31 \\
3 & $11-15$ & 24 & 24 \\
4 & $16-20$ & 1 & 1 \\
5 & $21-25$ & 7 & 7 \\
6 & $26-30$ & 3 & 3 \\
7 & $>31$ & 1 & 1 \\
\hline & Jumlah & $\mathbf{3 0}$ & $\mathbf{1 0 0 \%}$ \\
\hline
\end{tabular}

Sumber: Data Primer (2019)

Dari Tabel 4, dapat diambil kesimpulan bahwa rata-rata terbanyak responden baru bekerja selama $<5$ tahun yaitu sebanyak 33 orang. Dan rata-rata paling sedikit yaitu masa kerja antara 16-20 tahun dan juga $>31$ tahun yaitu sebanyak 1 orang. Hal ini 
disimpulkan bahwa pegawai terbanyak yang bekerja disektor publik Sumatera Barat masih terbilang memiliki masa kerja yang belum lama

\section{HASIL PENELITIAN}

Untuk mengetahui hasil penelitian tentang sikap karyawan terhadap perubahan dalam organisasi sektor publik di Sumatera Barat, maka dari hasil pengolahan data yang dilakukan untuk masing-masing variabel penelitian dilakukan deskripsi dengan tujuan menggambarkan proporsi jawaban responden terhadap variabel penelitian sebagai berikut:

a. Readiness for Change

Distribusi frekuensi variabel readiness for change terdiri dari lima indikator dan 27 pernyataan yang digunakan. Berikut ini akan dijelaskan mengenai distribusi frekuensi variabel readiness for change pada pegawai sektor publik Sumatera Barat.

Tabel 5. Distribusi Frekuensi Readiness for Change

\begin{tabular}{cccccc}
\hline No & Indikator & $\begin{array}{c}\text { Skor } \\
\text { Total }\end{array}$ & $\begin{array}{c}\text { Rerata } \\
\text { (mean) }\end{array}$ & $\begin{array}{c}\text { TCR } \\
\text { (\%) }\end{array}$ & Keterangan \\
\hline 1 & Case and vision & 1242 & 3,63 & 72,57 & Baik \\
2 & Change strategy & 2050 & 3,60 & 71,93 & Baik \\
3 & Change leadership & 2900 & 3,63 & 72,68 & Baik \\
4 & Empowerment climate & 1590 & 3,49 & 69,74 & Baik \\
5 & Enrolment & 3368 & 3,69 & 73,86 & Baik \\
\hline \multicolumn{2}{c}{ Rata-rata Indikator } & $\mathbf{2 2 3 0}$ & $\mathbf{3 , 6 1}$ & $\mathbf{7 2 , 1 6}$ & Baik \\
\hline
\end{tabular}

Sumber: Data Primer (2019)

Berdasarkan tabel diatas terlihat variabel readiness for change memiliki skor rata-rata 3,61 atau sebesar $72,16 \%$, yang berarti jawaban dari para responden berada pada kategori cukup tinggi, karena memenuhi kriteria pengklasifikasian rata-rata jawaban responden dengan nilai 60-80\%. Hal ini memperlihatkan bahwa sikap readiness for change pegawai sektor publik sudah cukup baik dan ini perlu dipertahankan serta ditingkatkan. Dari pernyataan-pernyataan yang terdapat dalam kuisioner, pernyataan pada indikator enrolment dan change leadership memperoleh skor tertinggi yaitu sebesar 3,69 dan 3,63 atau sebesar $73,86 \%$ dan $72,68 \%$. Sedangkan pernyataan dari indikator empowerment climate memperoleh skor terendah yaitu sebesar 3,49 atau sebesar 69,74\%. Hal ini berarti pegawai merasa bahwa iklim pemberdayaan dikantornya masih sangat kurang maka dari itu perlu upaya lebih lanjut untuk meningkatkan empowerment climate agar sikap readiness for change lebih tinggi lagi.

\section{b. Commitment to Change}

Distribusi variabel commitment to change terdiri dari tiga indikator dengan 18 
pernyataan yang digunakan. Berikut ini akan dijelaskan mengenai distribusi frekuensi variabel commitment to change pada pegawai sektor publik Sumatera Barat.

Tabel 6. Distribusi Frekuensi Commitment to Change

\begin{tabular}{cccccc}
\hline No & Indikator & $\begin{array}{c}\text { Skor } \\
\text { Total }\end{array}$ & $\begin{array}{c}\text { Rerata } \\
\text { (mean) }\end{array}$ & $\begin{array}{c}\text { TCR } \\
\text { (\%) }\end{array}$ & Keterangan \\
\hline \multirow{2}{*}{$\begin{array}{c}\text { Affective } \\
\text { Commitment to } \\
\text { change } \\
\text { Continuance }\end{array}$} & 2471 & 3,61 & 72,25 & Baik \\
\hline $\begin{array}{c}\text { Commitment to } \\
\text { change } \\
\text { Normative }\end{array}$ & 1958 & 3,44 & 68,70 & Baik \\
\hline$\quad \begin{array}{c}\text { Commitment to } \\
\text { change }\end{array}$ & 2865 & 3,59 & 71,80 & Baik \\
\hline Rata-rata Indikator & $\mathbf{2 4 3 1 , 3 3}$ & $\mathbf{3 , 5 5}$ & $\mathbf{7 0 , 9 2}$ & Baik \\
\hline
\end{tabular}

Sumber: Data Primer (2019)

Berdasarkan tabel 6 diatas terlihat variabel commitment to change memiliki skor rata-rata 3,55 atau sebesar 70,92\% yang berarti jawaban responden termasuk dalam kategori baik, karena memenuhi kriteria pengklasifikasian rata-rata jawaban responden dengan nilai $60-80 \%$. Hal ini memperlihatkan bahwa commitment to change pegawai sektor publik di Sumatera Barat sudah cukup baik dan ini perlu dipertahankan serta ditingkatkan lagi. Dari pernyataan-pernyataan yang tercantum dalam kuisioner, pernyataan pada indikator affective commitment to change memperoleh rata-rata tertinggi yaitu sebesar 3,61 atau $72,25 \%$. Hal ini berarti komitmen afektif untuk perubahan pada pegawai sektor publik sudah cukup baik. Sedangkan untuk rata-rata terendah terdapat pada indikator continuance commitment to change yaitu sebesar 3,44 atau sebesar $68,70 \%$.

\section{c. Opennes to Change}

Indikator variabel openess to change merupakan kesediaan untuk mengakomodasi atau menerima perubahan secara spesifik dan pandangan terhadap perubahan sebagai sesuatu yang positif untuk diri sendiri, pelanggan, dan organisasi. Deskripsi variabel openess to change dapat dilihat pada tabel berikut:

Tabel 7. Distribusi Frekuensi Variabel Opennes to change

\begin{tabular}{cccccc}
\hline No & Indikator & Skor Total & Rerata (mean) & TCR (\%) & Keterangan \\
\hline & $\begin{array}{c}\text { The willingness to accommodate } \\
\text { or accept specific changes }\end{array}$ & 1262 & 3,69 & 73,80 & Baik \\
\hline & $\begin{array}{c}\text { View of change as positive or } \\
\text { negative for themselves, } \\
\text { customers, and organization }\end{array}$ & 1692 & 3,71 & 74,21 & Baik \\
\hline & Rata-rata Indikator & $\mathbf{1 4 7 7 , 0 0}$ & $\mathbf{3 , 7 0}$ & $\mathbf{7 4 , 0 1}$ & Baik \\
\hline
\end{tabular}

Sumber: Data Primer (2019) 
Berdasarkan tabel 7 diatas terlihat bahwa variabel openess to change memiliki rata-rata 3,70 atau sebesar $74,01 \%$ yang berarti jawaban dari para responden termasuk dalam kategori baik, karena memenuhi kriteria pengklasifikasian rata-rata jawaban responden dengan nilai $60-80 \%$. Hal ini memperlihatkan bahwa sikap opennes to change pada pegawai sektor publik yang sedang mengalami perubahan di Sumatera Barat sudah baik, namun perlu dipertahankan dan ditingkatkan lagi. Dari pernyataanpernyataan yang dicantumkan dalam kuisioner, pernyataan pada indikator pandangan terhadap perubahan memperoleh rata-rata tertinggi yaitu sebesar 3,71 atau sebesar 74,21\%. Sedangkan indikator kesediaan untuk mengakomodasi perubahan memperoleh skor sebesar 3,69 atau sebesar 73,80\%. Hal ini menunjukan bahwa kesediaan pegawai sektor publik di Sumatera Barat untuk menerima perubahan sudah baik.

\section{d. Cynicism About Organizational Change}

Distribusi variabel sinisisme terhadap perubahan organisasi terdiri dari dua indikator dengan delapan pernyataan. Berikut ini akan dijelaskan mengenai distribusi frekuensi variabel sinisisme terhadap perubahan organisasi.

Tabel 8. Distribusi Frekuensi Variabel Cynicism about organizational change

\begin{tabular}{|c|c|c|c|c|c|}
\hline No & Indikator & Skor Total & $\begin{array}{l}\text { Rerata } \\
\text { (mean) }\end{array}$ & $\begin{array}{l}\text { TCR } \\
\text { (\%) }\end{array}$ & Keterangan \\
\hline 1 & Pesimisme & 1088 & 2,39 & 47,72 & Baik \\
\hline 2 & $\begin{array}{c}\text { Dispositional } \\
\text { attribution }\end{array}$ & 1037 & 2,33 & 45,48 & Baik \\
\hline \multicolumn{2}{|c|}{ Rata-rata Indikator } & 1062,50 & 2,33 & 46,60 & Baik \\
\hline
\end{tabular}

Berdasarkan tabel diatas terlihat variabel sinisisme terhadap perubahan organisasional memiliki skor tertinggi pada indikator pesimisme yaitu sebesar 2,39 atau $47,72 \%$ yang berarti jawaban dari para rospenden berada dalam kategori agak rendah, karena memenuhi kriteria pengklasifikasian rata-rata jawaban responden dengan nilai $40-60 \%$. Hal ini memperlihatkan bahwa masih terdapat pegawai sektor publik Sumatera Barat yang bersikap sinis terhadap perubahan organisasi. Dari pernyataan-pernyataan yang dicantumkan dalam kuisioner, pernyataan pada indikator pesimisme memperoleh rata-rata tertinggi yaitu 2,39 atau sebesar $47,72 \%$, sedangkan pada indikator dispositional attribution memperoleh rata-rata sebesar 2,33 atau sebesar $45,58 \%$. Hal ini berarti masih banyak pegawai sektor publik Sumatera Barat yang bersikap sinis terhadap perubahan organisasinya. Maka dari pada itu penting untuk dilakukan tindak lanjut agar sikap sinis tersebut dapat diturunkan. 


\section{PEMBAHASAN}

Organisasi harus berubah untuk menyesuaikan dengan lingkungannya. Perubahan ini dibuat agar organisasi dapat memenuhi target kinerja yang ada dan target kinerja masa depan (Oreg, Vakola, \& Armenakis, 2011). Menurut Arbaugh (2002), ada tiga jenis perubahan yang dilakukan oleh organisasi. Pertama, perubahan dalam bentuk pembangunan. Perubahan ini didefinisikan sebagai perbaikan internal dari hal-hal yang telah diketahui atau dipelajari oleh organisasi. Pengembangan ini menghadirkan peningkatan keterampilan, metode, standar kinerja, atau kondisi yang ada dan karena alasan tertentu tidak sesuai dengan kebutuhan organisasi sekarang atau di masa depan. Sedangkan bentuk perubahan kedua; perubahan transisi, mencakup aspek yang lebih kompleks. Perubahan ini terjadi karena respons terhadap perubahan signifikan dalam lingkungan sebagai persyaratan keberhasilan bagi suatu organisasi. Jenis perubahan terakhir, yaitu perubahan transformasional didefinisikan sebagai perubahan radikal dari strategi, struktur, sistem, proses, atau teknologi, sehingga membuat perubahan signifikan ke pola pikir budaya, perilaku, dan organisasi. Pergeseran signifikan ini bertujuan untuk mengimplementasikan program perubahan yang berhasil dan berkelanjutan.

Sangat penting bagi agen perubahan untuk mengetahui perbedaan antara ketiga jenis perubahan. Ini karena masing-masing jenis memiliki pendekatan yang berbeda dan perbedaan mempengaruhi reaksi terhadap program perubahan itu sendiri. Oleh karena itu, manajemen perubahan diperlukan untuk membantu mengimplementasikan program perubahan.

Manajemen perubahan pada dasarnya menggabungkan proses konsultasi manusia dengan intervensi teknis yang bertujuan untuk mengubah sistem dan struktur organisasi. Untuk membuat program perubahan berhasil, manajemen perubahan memerlukan integrasi semua komponen dalam organisasi, dan salah satu faktor terpenting adalah manusia. Sikap manusia, dalam hal ini karyawan, memiliki pengaruh signifikan terhadap perilaku yang ditunjukkan selama proses perubahan (Vakola, Tsaousis, \& Nikolaou, 2004). Penelitian ini menemukan bahwa respons karyawan terhadap perubahan dapat dilihat dari sikap paling positif (optimis dan tertarik pada keberhasilan program perubahan) hingga sikap paling negatif (resistensi terhadap perubahan). Choi (2011) menemukan bahwa sifat manusia akan bereaksi lebih kuat terhadap hal-hal negatif. Jadi, setiap kali perubahan organisasi terjadi, tujuan positif perubahan akan selalu dibayangi oleh respons negatif yang mengarah pada niat untuk menolak perubahan.

Penelitian sebelumnya oleh Choi (2011) menunjukkan bahwa ada empat konstruksi yang mewakili sikap karyawan terhadap perubahan organisasi; kesiapan untuk berubah, komitmen terhadap perubahan, keterbukaan terhadap perubahan dan sinisisme terhadap perubahan organisasional. Penelitian ini juga menyatakan bahwa ada beberapa anteseden yang mempengaruhi empat konstruksi, yang kemudian 
dikelompokkan menjadi empat dimensi: konteks perubahan, proses perubahan, konten perubahan, dan faktor individu. Setiap dimensi memiliki pengaruh berbeda pada sikap karyawan terhadap perubahan. Penelitian ini ingin melihat keempat sikap karyawan terhadap perubahan organisasi.

Readiness for change atau kesiapan pegawai dalam menghadapi perubahan dalam penelitian ini dapat dikategorikan cukup baik. Hal ini berarti karyawan sudah merasa cukup yakin mereka mampu melalui proses perubahan dengan baik (Choi, 2011). Selain itu, pegawai juga merasakan bahwa perubahan yang ada di organisasinya memang diperlukan. Pegawai merasakan bahwa perubahan akan mendatangkan manfaat bagi mereka. Pegawai pada organisasi sektor publik di Sumatera Barat juga merasakan dukungan organisasi dan atasan terhadap perubahan yang terjadi. Banyak faktor yang mempengaruhi kesiapan pegawai terhadap perubahan, diantaranya budaya organisasi, kemampuan organisasi untuk berubah dan sikap pegawai di tempat kerja.

Commitment to change atau komitmen pegawai terhadap perubahan dalam penelitian ini termasuk dalam kategori baik. Hasil ini menujukkan bahwa pegawai di organisasi yang diteliti merasa bahwa mereka akan mendapatkan manfaat dari perubahan. Pegawai di organisasi sektor publik di Sumatera Barat juga merasa berkewajiban untuk memberikan dukungan terhadap perubahan yang ada di organisasinya. Mereka juga mengetahui resiko yang harus dihadapi apabila perubahan yang terjadi mengalami kegagalan. Faktor-faktor yang dapat mempengaruhi komitmen pegawai organisasi terhadap perubahan antara lain hubungan antar pegawai, integrasi di organisasi, kepuasan kerja, kepemimpinan dan keadilan organisasional (Herscovitch \& Meyer, 2002).

Openness to change atau keterbukaan dalam menerima perubahan merupakan variabel dengan nilai paling tinggi dalam penelitian ini. Hasil ini menunjukkan bahwa pegawai pada organisasi sektor publik di Sumatera Barat terbuka terhadap perubahan. Individu dalam organisasi yang diteliti menanti dengan antusias setiap perubahan yang terjadi di organisasinya (Devos et al., 2007). Selain itu, perubahan yang terjadi diyakini akan membuat pekerjaan mereka menjadi lebih mudah. Keterbukaan terhadap perubahan dipengaruhi oleh informasi yang beredar mengenai perubahan, kepercayaan individu terhadap organisasi dan partisipasi dalam perubahan.

Sinisisme terhadap perubahan organisasional merupakan pesimisme terhadap kemungkinan kesuksesan atau kegagalan suatu perubahan. Sinisisme terhadap perubahan organisasional juga mengacu kepada kecenderungan untuk menyalahkan pihak organisasi dan manajemen terhadap kegagalan yang ada di organisasi . Pada penelitian ini, tingkat sinisisme terhadap perubahan organisasional sudah cukup rendah. Sinisisme terhadap perubahan organisasional dipengaruhi oleh iklim pengambilan keputusan dalam organisasi, kepemimpinan dan keadilan organisasional. 
Berbagai masalah yang terjadi dalam implementasi perubahan yang menyebabkan sistem tidak berjalan atau tidak diharapkan untuk berjalan dengan baik harus ditata ulang atau diperbarui. Reformasi birokrasi dilaksanakan untuk mewujudkan pemerintahan yang baik. Reformasi birokrasi adalah perubahan strategis untuk mereformasi karyawan dalam organisasi publik menjadi lebih efisien dan efektif dalam melaksanakan tugas, tugas, dan tanggung jawab mereka sebagai pegawai pemerintah dan bagian dari pembangunan nasional. Selain itu, dengan kemajuan pesat ilmu pengetahuan, teknologi informasi dan komunikasi dan lingkungan strategis, perubahan menuntut birokrasi pemerintah untuk direformasi dan disesuaikan ke dalam dinamika dengan tuntutan masyarakat. Oleh karena itu, organisasi sektor publik harus mengambil perubahan yang mendasar, komprehensif, dan sistematis, sehingga tujuan dan sasaran yang telah ditetapkan dapat tercapai secara efektif dan efisien. Reformasi di sini adalah proses pembaruan bertahap dan berkesinambungan, sehingga tidak mencakup upaya dan tindakan radikal dan revolusioner.

Penelitian ini akan membantu organisasi sektor publik untuk mengatasi perubahan. Ini akan membantu organisasi publik untuk memahami sikap karyawan mereka selama perubahan.

\section{KESIMPULAN DAN SARAN}

Penelitian ini bertujuan untuk menguji empat konstruk yang mewakili sikap karyawan terhadap perubahan organisasi; kesiapan untuk berubah, komitmen untuk berubah, keterbukaan untuk berubah dan sinisisme terhadap perubahan organisasi. Penelitian ini akan membantu organisasi publik untuk mengatasi perubahan. Ini akan membantu organisasi publik untuk memahami sikap karyawan mereka selama perubahan. Hasil penelitian menunjukkan bahwa keterbukaan terhadap perubahan memiliki rata-rata tertinggi, diikuti oleh kesiapan untuk berubah, komitmen untuk berubah dan sinisisme terhadap perubahan organisasi. Ini berarti bahwa karyawan di organisasi publik di Sumatera Barat bersedia untuk mengakomodasi dan menerima perubahan.

Untuk penelitian selanjutnya, peneliti bisa menguji faktor-faktor yang mempengaruhi sikap karyawan terhadap perubahan organisasi. Selain itu, dapat juga diteliti mengenai pengaruh sikap karyawan terhadap kesuksesan atau kegagalan sebuah program perubahan.

\section{DAFTAR PUSTAKA}

Ahmad, A. B., \& Cheng, Z. (2018). The Role of Change Content, Context, Process, and Leadership in Understanding Employees' Commitment to Change: The Case of Public Organizations in Kurdistan Region of Iraq. Public Personnel Management.

Arbaugh, J. B. (2002). Beyond Change Management: Advanced Strategies for Today's 
Transformational Leaders (Book). Academy of Management Learning \& Education.

Armenakis, A. A., Harris, S. G., \& Mossholder, K. W. (1993). Creating Readiness for Organizational Change. Human Relations.

Bommer, W. H., Rich, G. A., \& Rubin, R. S. (2005). Changing attitudes about change: Longitudinal effects of transformational leader behavior on employee cynicism about organizational change. Journal of Organizational Behavior.

Choi, M. (2011). Employees' attitudes toward organizational change: A literature review. Human Resource Management.

Choi, M., \& Ruona, W. E. A. (2011). Individual readiness for organizational change and its implications for human resource and organization development. Human Resource Development Review.

Devos, G., Buelens, M., \& Bouckenooghe, D. (2007). Contribution of content, context, and process to understanding openness to organizational change: Two experimental simulation studies. Journal of Social Psychology.

Fedor, D. B., Caldwell, S., \& Herold, D. M. (2006). The effects of organizational changes on employee commitment: A multilevel investigation. Personnel Psychology.

Herscovitch, L., \& Meyer, J. P. (2002). Commitment to organizational change: Extension of a three-component model. Journal of Applied Psychology.

Oreg, S., Vakola, M., \& Armenakis, A. (2011). Change recipients' reactions to organizational change: A 60-year review of quantitative studies. Journal of Applied Behavioral Science.

Reichers, A. E., Wanous, J. P., \& Austin, J. T. (2010). and managing cynlicism about organizational change. The Academy of Management Executive.

Vakola, M., Tsaousis, I., \& Nikolaou, I. (2004). The role of emotional intelligence and personality variables on attitudes toward organisational change. Journal of Managerial Psychology. 